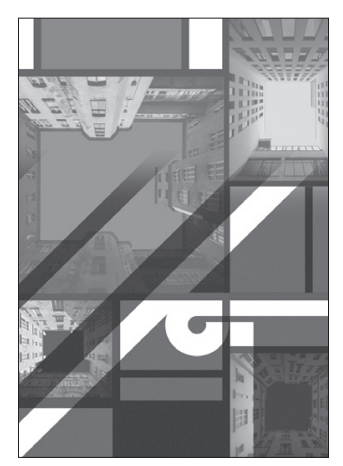

\title{
Krzysztof Koszewski*
}

\author{
Wspótczesne praktyki wizualne w architekturze \\ a dydaktyka architektoniczna
}

\section{Modern visual practices in architecture and architectural didactics}

\section{Wprowadzenie \\ - reinterpretacja dziedzictwa Bauhausu}

Walter Gropius w pierwszym zdaniu manifestu Bauhausu napisał: Ostatecznym celem wszystkich sztuk (wizualnych) jest budowla ${ }^{1}$. Zdanie to, jak i dalsza część broszury programowej wydanej w 1919 r. [3], deklaruje jedność sztuk pod wodzą architektury. Wybrzmiewa tu koncept Gesamtkunstwerk - uniwersalnego języka sztuki, która urzeczywistnia się najpełniej, według Gropiusa, właśnie w dziele architektury. Wassily Kandinsky, zastępca dyrektora szkoły w latach 1923-1933, dokonując w swojej książce Punkt i linia a płaszczyzna formalnych analiz kompozycyjnych w duchu Bauhausu, również przywołuje ową jedność sztuk, włączając w to nawet szersze ich spektrum (także muzykę i poezję), i w ten sposób definiuje tło teoretyczne dla analiz architektury [4, s. 104-108]. Jeśli dodamy do tego wyraźne akcenty kładzione w dydaktyce Bauhausu na działalność rzemieślniczą i związane $\mathrm{z}$ nią umiejętności, otrzymamy obraz, w którym

* ORCID: 0000-0002-7907-746X. Wydział Architektury Politechniki Warszawskiej / Faculty of Architecture, Warsaw University of Technology, e-mail: krzysztof.koszewski@pw.edu.pl

1 Zdanie to, brzmiące w oryginale Das Endziel aller bildnerischen Tätigkeit ist der Bau! [1, s. 1], jest różnie thumaczone na język polski. Tłumaczenie przyjęte na wstępie artykułu pochodzi od autora, można też znaleźć inne jego wersje, najczęściej pochodzące z niebezpośrednich przekładów: Kompletna budowla jest ostatecznym celem sztuk plastycznych [2, s. 35], Ostatecznym celem każdej twórczej działalności jest budowanie [3, s. 12]. Wielość tłumaczeń daje pole do różnych interpretacji tego stwierdzenia, przy czym wydaje się, że taka też mogła być intencja piszącego - by odnosić je zarówno do konkretnego budynku, jak i do samej idei projektowania.

\section{Introduction - reinterpretation of Bauhaus heritage}

In the first sentence of the Bauhaus manifesto Walter Gropius says: The ultimate goal of all (visual) arts is a building ${ }^{1}$. This statement and the remaining part of the programme brochure published in 1919 [3] declares the unity of arts under the primacy of architecture and what echoes here is the concept of Gesamtkunstwerk - a universal language of art, which, according to Gropius, is realised at its fullest in architecture. While conducting formal composition analyses in his book Point and Line to Plane, written in the spirit of Bauhaus, Wassily Kandinsky, vice-master of the school in 1923-1933, invokes the aforementioned unity of arts, including even a wider art spectrum (complemented by music and poetry). This way he defines the theoretical background for architectural analyses [4, pp. 104-108]. And if we add to this a heavy emphasis placed on craftmanship and related skills in the Bauhaus didactics, we get the picture in which teaching fine arts to architects, including teaching relevant skills and developing sensitivity, is of direct benefit to the design process, enriching it and making it more conscious, and first and foremost creative. However, nowadays this concept, which cannot be denied validity even today, should be complemented with the issues of the visual

1 The German sentence Das Endziel aller bildnerischen Tätigkeit ist der Bau! [1, p. 1] is translated in different ways in Polish [2, p. 35], [3, p. 12]. Myriads of translations open the door to various interpretations of this statement. Nevertheless, it seems that this might have been the writer's idea - to make a reference both to a specific building and the idea of design itself. 
kształcenie architektów w zakresie sztuk plastycznych, w tym kształtowanie odpowiednich umiejętności i wrażliwości, służy bezpośrednio procesowi projektowania, czyniąc go pełniejszym i bardziej świadomym, a przede wszystkim - kreatywnym. Koncepcja ta, której nie można odmówić słuszności i dziś, powinna jednak zostać obecnie uzupełniona o problematykę dotyczącą wizualnego charakteru współczesnej kultury jako podstawowego kontekstu działań związanych z komunikowaniem idei architektonicznych. Ten dodatkowy wątek jest często pomijany w procesie reinterpretacji dziedzictwa Bauhausu, sprowadzanego do konceptu jedności sztuk w zakresie samego procesu projektowego, a niekiedy wręcz do roli umiejętności warsztatowych w nauczaniu przyszłych architektów. Ów szerszy kontekst, wykraczający poza działania $w$ ramach samego projektowania i związane z nimi umiejętności jest zresztą sygnalizowany przez samego Gropiusa, który tak pisał po latach o idei kształcenia w Bauhausie: Obecnie od samego poczatku nauki zbyt duza wage przywiazuje się do tradycyjnego, specjalistycznego przeszkolenia, w trakcie którego uczniowi przekazuje się fachowa wiedze, nie objaśniajac jednak znaczenia czy celu jego pracy ani związu między twórca a światem. Przeciwko takiemu podejściu zaprotestowat Bauhaus, rozpoczynajac szkolenie nie od „profesji”, lecz od „,czlowieka” posiadajacego wrodzona predylekcję do postrzegania życia jako całości [5, s. 30]. Sto lat po wprowadzeniu w życie tych założeń, gdy ów świat, z którym wchodzi w relację twórca-architekt, jest daleko bardziej skomplikowany i zmienny, można wspomniane ,życie jako całość" interpretować jako kulturowy kontekst architektury. Mówiąc tu o sztukach plastycznych, czy też szerzej, kompetencjach wizualnych, należy dyskurs dotyczący nauczania architektury uzupełnić o problematykę analiz semiotycznych, umieszczając w polu zainteresowań ikonologię obrazów architektury, sytuując ją jednocześnie w perspektywie przemian kulturowych związanych ze zwrotem obrazowym i przestrzennym ${ }^{2}$. Jest to obszar badawczy eksplorowany na polu nauk humanistycznych, często niedoceniany przez samych architektów, którzy jeśli nawet wypowiadają się o współczesnej kulturze wizualnej, to robią to bardzo krytycznie ${ }^{3}$. Być może z tego powodu znaczenie praktyk wizualnych w architekturze bywa sprowadzane do kwestii czysto warsztatowych, podczas gdy mogą mieć one kluczowy wpływ na samo dzieło. Pierwsze zdanie manifestu Gropiusa, przywołane na wstępie, można odczytać także jako odniesienie do konkretnego procesu projektowania, w którym celem wszelkiej aktywności wizualnej jest wzniesienie budynku. Obecna rola obrazów i praktyk wizualnych w warsztacie architekta wykracza jednak daleko poza tę zależność praktyczno-celową, pozostając nie bez wpływu na samą możliwość urzeczywistnienia dzieła. Tworzony

\footnotetext{
2 Zwrot obrazowy, zadeklarowany w artykule Wiliama J.T. Mitchella z 1992 r. [6] dał początek nurtowi analizującemu rolę obrazów we współczesnej, zmediatyzowanej kulturze.

3 Należy tu wskazać choćby liczne niezwykle krytyczne wypowiedzi przedstawicieli nurtu fenomenologicznego w architekturze, takich jak Juhani Pallasmaa, Steven Holl, Alberto Perez-Gomez.
}

character of modern culture as the fundamental context for activities related to communicating architectural ideas. More often than not, this extra idea is neglected in the process of reinterpretation of the Bauhaus heritage, which is frequently reduced to the concept of arts unity in the design process itself, and sometimes even to the role of skills and tools in teaching future architects. The wider context, which goes beyond the design process itself and the related skills, was mentioned by Gropius himself, who wrote about the idea of teaching at Bauhaus in this way: The fact that the man of today is, from the outset, left too much to traditional specialized training - which merely imparts to him a specialized knowledge, but does not make clear to him the meaning and purport of his work, nor the relationship in which he stands to the world at large - was counteracted at the Bauhaus by putting at the beginning of its training not the "trade" but the "human being" in his natural readiness to grasp life as a whole ${ }^{2}$ $[5$, p. 30]. A hundred years after implementing those ideas, when the world with which a creator-architect begins a relationship is far more complicated and changeable, one may interpret the aforementioned "life as a whole" as a cultural context for architecture. When talking about visual arts, or even visual competences, the discourse on teaching architecture should be complemented with semiotic analyses, placing the iconology of architectural images in the field of interest, and at the same time placing it in the perspective of cultural transformations connected with the visual and spatial turn ${ }^{3}$. This is a research area explored in the field of humanistic studies, which is very often undervalued by architects themselves who even if they talk about the visual culture, they do so in a very critical way ${ }^{4}$. Perhaps for this reason the meaning of visual practices in architecture often boils down to pure skills and tools, whereas these practices can have tremendous influence on the work itself. The first sentence of the Gropius manifesto, quoted at the beginning, can be interpreted as a reference to a specific process of design, in which constructing a building is the goal of all visual activity. However, the current role of images and visual practices in the architect's skills and tools is something much more than this practical and objective dependence and does not remain without an impact on the possibility of implementing the work. The visual message created, easily freed from the constraints of idea-image-work sequence corresponding to the logic of the design process, operates in the social consciousness as an independent entity, quite often outside the designer's control, frequently evolving with its connotations and meanings in an unexpected direction. The purpose of the research presented in this paper is to indicate the sources and operating mechanisms of these

\footnotetext{
2 Gropius W., Scope of Total Architecture, Collier Books, Toronto, 1970, p. 23.

3 Pictorial turn defined by William J.T. Mitchell in the article published in 1992 [6] began a trend analysing the role of images in the modern media-controlled culture.

4 Numerous incredibly critical opinions made by the representatives of the phenomenological trend in architecture should be mentioned here, including Juhani Pallasmaa, Steven Holl and Alberto Perez-Gomez.
} 
przekaz obrazowy, uwalniając się bardzo łatwo z rygorów sekwencji idea-obraz-dzieło, odpowiadającej logice procesu projektowania, funkcjonuje w świadomości społecznej jako niezależny byt, nierzadko poza kontrolą projektanta, ewoluując ze swoimi konotacjami i znaczeniami w często nieoczekiwanym kierunku. Celem prezentowanych w niniejszym artykule badań jest wskazanie źródeł i mechanizmów działania owych konotacji, jak również zbadanie relacji tworzonych obrazów dzieła architektury z jego odbiorem jako wzniesionego budynku. Rozważania te umieszczono w kontekście założeń dydaktyki architektonicznej opracowanych przez Waltera Gropiusa dla Bauhausu.

\section{Obrazy architektury jako element kultury wizualnej}

Wizualny charakter kultury współczesnej, wzmacniany w ciągu XX w. wielokrotnie przez takie zjawiska, jak rozpowszechnienie kolorowego druku offsetowego, telewizji, czy w końcu Internetu, miał niewątpliwie wpływ na postrzeganie roli obrazów architektury w jej aspektach wykraczających poza proces projektowania (i związanej z nim reprezentacji idei). Była ona jednak kojarzona w zbiorowej świadomości głównie $\mathrm{z}$ wizualnymi symbolami pewnych zjawisk w architekturze, do czego zresztą przyczyniali się sami architekci czy krytycy architektury. Jednym z przykładów tego typu funkcji obrazu jest zdjęcie osiedla Pruitt-Igoe w momencie jego wysadzania w powietrze 15 lipca 1972 r. (il. 1), odczytywane za sprawą Charlesa Jencksa jako symbol końca epoki modernizmu ${ }^{4}$.

Tymczasem, wraz z rozwojem technik wizualizacji pozwalających na coraz wierniejszą symulację wizerunku projektowanej rzeczywistości ${ }^{5}$, rosła też rola tworzonych w ten sposób obrazów jako reprezentacji idei architektonicznej. Dało się tu zauważyć tendencję to postrzegania tak wytworzonych reprezentacji w kategoriach fotografii, ze szczególnym uwzględnieniem jej kulturowego wydźwięku jako świadectwa ukazywanej rzeczywistości ${ }^{6}$. Następuje tu ciekawa sprzeczność, albowiem kulturowe schematy odczytania fotografii (utrwalonego, zamrożonego momentu w przeszłości) przykładane są do reprezentacji jeszcze nieucieleśnionych idei, czego najlepszym przykładem są gorące dyskusje, które wywołują. Mamy tu do czynienia z zjawiskiem odwróconej retrospekcji - utrwalenia momentu (przynajmniej w kategoriach jego postrzegania), który jeszcze nie nastąpił. Ma to istotne konsekwencje dla procesu powstawania dzieła architektury, a wręcz także dla samej możliwości jego realizacji. Świadomość tych

${ }^{4}$ Zdjęcie to ilustruje rozdział książki Charlesa Jencksa zatytułowany „Śmierć architektury modernistycznej” [7, s. 9].

5 Chodzi tu w istocie o symulację fotografii nieistniejącego obiektu, albowiem mechanizmy tworzenia płaskiego obrazu na podstawie przekształceń geometrycznych zaczerpnięte są z praw optyki, łącznie $\mathrm{z}$ zastosowaniem $\mathrm{w}$ programach do modelowania terminologii fotograficznej, np. długości ogniskowej wirtualnego obiektywu.

6 Roland Barthes pisał w przypadku zdjęć wręcz o ,wskrzeszeniu” tego, co fotografia ukazuje, czyli swoistej re-prezentacji; zob. [8, s. 139].

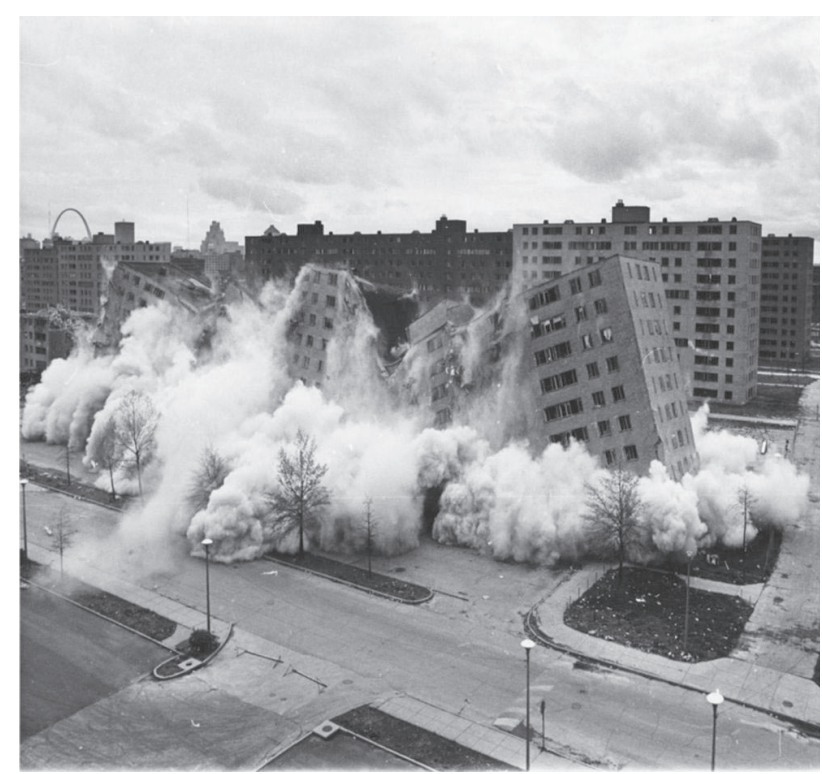

I1. 1. Wyburzanie osiedla Pruitt-Igoe w Saint Louis, zdjęcie z 15 lipca 1972 r. (źródło: U.S. Department of Housing and Urban Development Office of Policy Development and Research - Creating Defensible Space, https://commons.wikimedia.org/w/index. php?curid=803832, domena publiczna)

Fig. 1. Demolition of the Pruitt-Igoe housing estate in Saint Louis, photo taken on July 15, 1972 (source: U.S. Department of Housing and Urban Development Office of Policy Development and Research - Creating Defensible Space, https://commons.wikimedia.org/w/index. php?curid=803832, public domain)

connotations, as well as analyse the relationship between the created images of the architectural work with its reception as a constructed building. The analyses are made in the context of the tenets of architectural didactics created by Walter Gropius for Bauhaus.

\section{Architectural images as an element of visual culture}

The visual character of modern culture, many times enhanced in the $20^{\text {th }}$ century by the phenomena such as the widespread use of colour offset printing, television, and, in the end, the Internet, has undoubtedly had an impact on the perception of the role of architectural images in its aspects transcending the design process (and the representation of the related idea). However, in the collective consciousness it was mainly associated with visual symbols of certain architectural phenomena to which architects or architectural critics contributed themselves. One of the examples of such a function of image is the photo of the Pruitt-Igoe housing estate taken during its demolition by explosion on July 15, 1972 (Fig. 1), thanks to Charles Jencks interpreted as the symbol of the end of the modernist era ${ }^{5}$.

In the meantime, visualisation technologies which facilitated an increasingly accurate simulation of images of

\footnotetext{
5 The photo illustrates a chapter titled "The Death of Modern Architecture" in a book by Charles Jencks [7, p. 9].
} 


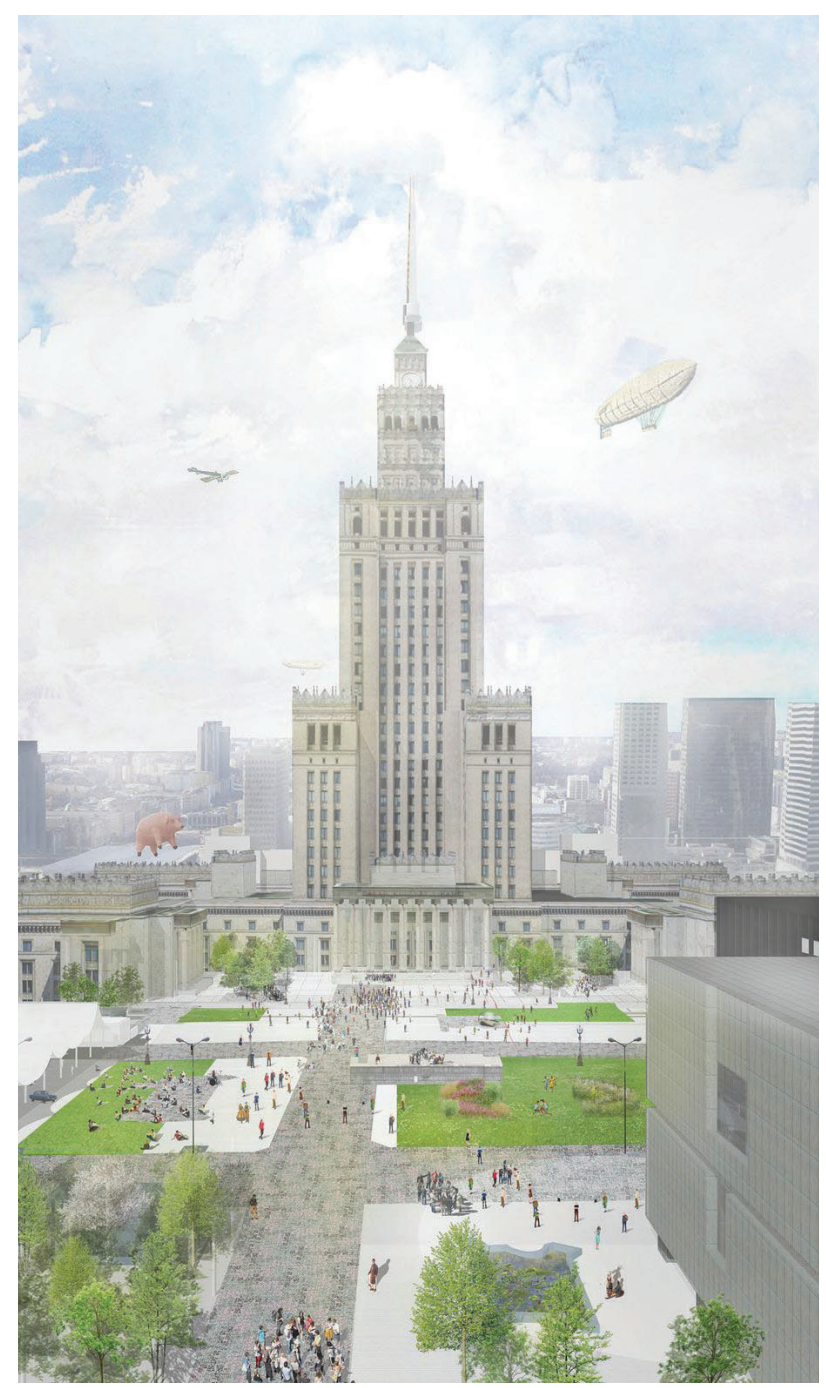

Il. 2. Wizualizacja zwycięskiego projektu Placu Centralnego w Warszawie, autorzy A-A Collective

(Z. Borawski, M.M. Larsen, S. Zlokapa)

(źródło: dzięki uprzejmości autorów)

Fig. 2. Visualisation of a winning project of Central Square in Warsaw, designers A-A Collective

(Z. Borawski, M.M. Larsen, S. Zlokapa)

(source: courtesy of the authors)

procesów jest kluczowa dla zrozumienia roli obrazów architektury we współczesnej kulturze wizualnej, ta zaś pozostaje niezbędna do skutecznego i świadomego ich tworzenia.

Można mnożyć przykłady ogromnego znaczenia sposobu, w jaki odczytywane są obrazy będące reprezentacjami idei architektonicznej. Ich szczegółowa analiza wykracza poza ramy tego artykułu, warto jednak przytoczyć charakterystyczny przykład sytuacji, gdy interpretacje obrazu usunęły w cień - przynajmniej początkowo - dyskusję na temat istoty proponowanych rozwiązań. Chodzi o zwycięski projekt zagospodarowania Placu Centralnego w Warszawie, wyłoniony w dwuetapowym konkursie, wykonany przez pracownię A-A Collective (Zygmunt Borawski, Marin Marker Larsen, Srdjan Zlokapa), zaprezentowany w serii wizualizacji. Na jednej z nich (il. 2) pojawił się niewielki wizerunek unoszącej się w powietrzu projected reality were developing ${ }^{6}$, and the role of images created with these technologies as representations of architectural ideas was growing in importance as well. One could notice a tendency to perceive representations created this way as photographs, with particular emphasis on their cultural resonance as the evidence of a depicted reality ${ }^{7}$. An interesting contradiction occurs here, since cultural schemas for interpreting photographs (a captured moment, frozen in the past) are applied to the representations of still non-embodied ideas, with heated discussions they provoke as best evidence. This phenomenon is known as reverse retrospection - capturing a moment (at least in its perception categories) which has not happened yet. It has significant consequences for the process of creating a piece of architecture, and even for the possibility of its implementation itself. The awareness of these processes is key to understanding the part architectural images play in modern visual culture, which remains indispensable for their effective and conscious creation.

One can give numerous examples of the significance of the way in which images representing architectural ideas are interpreted. Their detailed analysis is beyond the scope of this paper, but it is worth mentioning an exemplary situation when image interpretations, at least initially, overshadowed the discussion on the essence of the suggested solutions. This refers to the winning development project of Central Square in Warsaw, selected in a two-stage competition, designed by A-A Collective architectural design studio (Zygmunt Borawski, Marin Marker Larsen, Srdjan Zlokapa), presented in a series of visualisations. One of the visualisations (Fig. 2) contained a small image of a pig floating in the air ${ }^{8}$ which provoked a heated discussion ${ }^{9}$. Those images began a sort of life of their own, attracting comments which attributed totally new unexpected meanings to them, and becoming a certain cultural fact.

\section{The study of image reception in relation to the erected building}

The aforementioned example points to the importance of the creation and interpretation of visual messages related to communicating information about the architectural idea. In order to examine the way the visual messages were perceived, a survey on the mode of presentation of

6 This is about a simulation of a photograph of a non-existent building, as the mechanisms of creating a flat image based on geometrical transformations are extracted from the laws of optics, including the application of the photographic terminology in modelling programmes, e.g. the focal length of a virtual lens.

7 When talking about photographs, Roland Barthes wrote about even "resurrecting" what the photograph shows, that is a kind of re-presentation. See: [8, p. 139].

8 The designers confirmed that the image made a reference to a pop-cultural motif appearing in a photograph used on the cover of a record by a British group Pink Floyd - "The Animals". Judging by the reactions, the image was not initially interpreted this way.

9 One of numerous comments is quoted here: People were stirred up not by the tenets of the project, but by surprising elements in one of the visualisations. One can see an airship flying above the city and a pig floating in the air. And it was that animal that provoked such a deluge of comments [9]. 
świni ${ }^{7}$, wokół którego rozgorzała gorąca dyskusja ${ }^{8}$. Obrazy te zaczęły niejako żyć własnym życiem, obrastając w komentarze nadające im nowe, zgoła nieoczekiwane znaczenia, i stając się pewnym faktem kulturowym.

\section{Badanie odbioru obrazu $w$ relacji do wzniesionego budynku}

Przytoczony przykład wskazuje na wage problemu tworzenia i interpretacji komunikatów wizualnych związanych z przekazem informacji o idei architektonicznej. W celu zbadania sposobu ich odbioru przeprowadzone zostało w latach 2018-2019 badanie ankietowe dotyczace przedstawień warszawskiego budynku mieszkalnego przy ul. Złotej 44 projektu Daniela Liebeskinda9. W badaniu wzięli udział studenci pierwszego i drugiego roku na kierunku architektura na Wydziale Architektury Politechniki Warszawskiej. Taka grupa i obiekt wybrane zostały celowo ze względu na kilka przesłanek:

- sposób odbioru komunikatów wizualnych dotyczących architektury przez studentów może przynieść wnioski dotyczące procesu kształcenia - interesujące jest, jak są odbierane owe komunikaty przez tych, którzy jednocześnie zdobywają kompetencje dotyczące tworzenia takich obrazów, będąc tym samym grupą o zwiększonej świadomości wizualnej,

- studenci początkowych lat wybrani zostali celowo, by uniknąć potencjalnego rutynowego nastawienia do sposobów formułowania komunikatów wizualnych, które może być udziałem studentów lat wyższych,

- wybrany został budynek, który znany jest studentom z bezpośredniego oglądu, mogą zatem swoje sądy wyrażone w badaniu odnieść do własnych wrażeń; jednocześnie jest to obiekt, który ma zestaw utrwalonych konotacji wizualnych, funkcjonując w ten sposób w ikonosferze $\mathrm{e}^{10}$.

Punktem wyjścia do przygotowania badania było zestawienie dwu obrazów, które obiegło media społecznościowe w 2013 r., intencjonalnie ukazując rozbieżność rzeczywistego wizerunku ukończonego właśnie wieżowca z jego wizualizacjami publikowanymi wcześniej (il. 3).

7 Wizerunek ten był, co potwierdzili autorzy projektu, nawiązaniem do popkulturowego wątku pojawiającego się w fotografii wykorzystanej jako motyw okładki płyty brytyjskiej grupy Pink Floyd - „The Animals”. Jak wskazują reakcje, nie został początkowo jako taki odczytany.

8 Przytoczyć można jeden z wielu komentarzy: Emocje rozgrzaty jednak nie założenia projektu, a zaskakujace elementy na jednej z wizualizacji. Widać na niej między innymi lecacy nad miastem sterowiec i unoszaca się w powietrzu świnię. I to właśnie ten zwierzak wywołał lawinę komentarzy [9].

${ }^{9}$ Badanie to było prezentowane przez autora niniejszego artykuhu w książce Obrazy architektury: reprezentacje idei architektonicznej w kontekście wspótczesnej kultury wizualnej [10, s. 144, 145], dotyczyło jednak stanu badań w czasie jej publikacji. Wyniki prezentowane tutaj zostały poszerzone o kolejny rocznik studentów (większa liczba respondentów). Dodany został także, oprócz ilościowego, aspekt jakościowy badania (komentarze respondentów nieomawiane wcześniej), który pozwolił na wyciagnięcie nowych wniosków.

10 Pojęcie ,ikonosfera” rozumiane jest tu - w znaczeniu wprowadzonym przez Mieczysława Porębskiego - jako ogół otaczających nas obrazów, będących zarówno artefaktami, jak i wizualną manifestacją rzeczy stworzonych przez człowieka, a także tych naturalnych. To rodzaj wizualnego środowiska, w którym jesteśmy zanurzeni [11, s. 271]. the residential building at 44 Zlota Street in Warsaw designed by Daniel Liebeskind was conducted during the years 2018-201910. The respondents of the survey were first- and second- year students of Architecture at the Warsaw University of Technology. This group and object were selected intentionally for the following reasons:

- the way of interpreting visual messages related to architecture may lead to conclusions regarding the educational process - it is interesting how these messages are received by those who are simultaneously acquiring competences in creating such images, thus being a group of heightened visual awareness,

- students of the beginning years were selected intentionally so as to avoid a potentially routine attitude to the way of formulating visual messages, which may be shared among students of later years,

- the selected building was known to students through direct viewing, therefore they were able to relate their opinions expressed in the survey to personal impressions. It is at the same time a building with established visual connotations, thus functioning in iconosphere ${ }^{11}$.

The starting point for preparing the survey was a comparison (or juxtaposition) of two images, which was disseminated in social media in 2013, and intentionally showed the discrepancy between the real image of a newly completed skyscraper and its visualisations which were published earlier (Fig. 3) The visualisation was prepared for the needs of the skyscraper project by using the location image as a background (the editing was performed here, which consisted, among other things, in eliminating the third vanishing point and tonal adjustments of the darker parts), in which a synthetic image of the building, created on the basis of a virtual 3D model, was inserted. In turn, the photograph which was used in the comparison gives an impression of having been taken with a smartphone, without any editing.

The cited comparison raises the question to what extent a different provenance of the images determines their perception, to what degree a synthetic character of the former one dictates that it can be commented on as not corresponding to reality.

The photorealistic ${ }^{12}$ character of the visualisation invokes the question whether, by means of using the accessible

10 This study was presented by the author of this article in the book Obrazy architektury: reprezentacje idei architektonicznej $w$ kontekście współczesnej kultury wizualnej [Images of Architecture: representations of architectural ideas in the context of contemporary visual culture] [10, pp. 144, 145]; however, it concerned the state of research at the time of its publication. The results presented here additionally included the subsequent year of studies (a higher number of respondents). Moreover, the qualitative aspect, apart from the quantitative one was added (comments of respondents not discussed earlier), which made it possible to draw new conclusions.

11 The notion of "iconosphere" is understood here - in the meaning introduced by Mieczysław Porębski - as the entirety of surrounding images, which are artefacts as well as a visual manifestation of things created by man, and the natural ones. It is a kind of visual environment, in which we are immersed [11, p. 271].

12 The expression "photorealistic", although commonly accepted, should be replaced with "photomimetic" for the sake of discourse reliability by way of analogy between realism and mimetism in arts. 


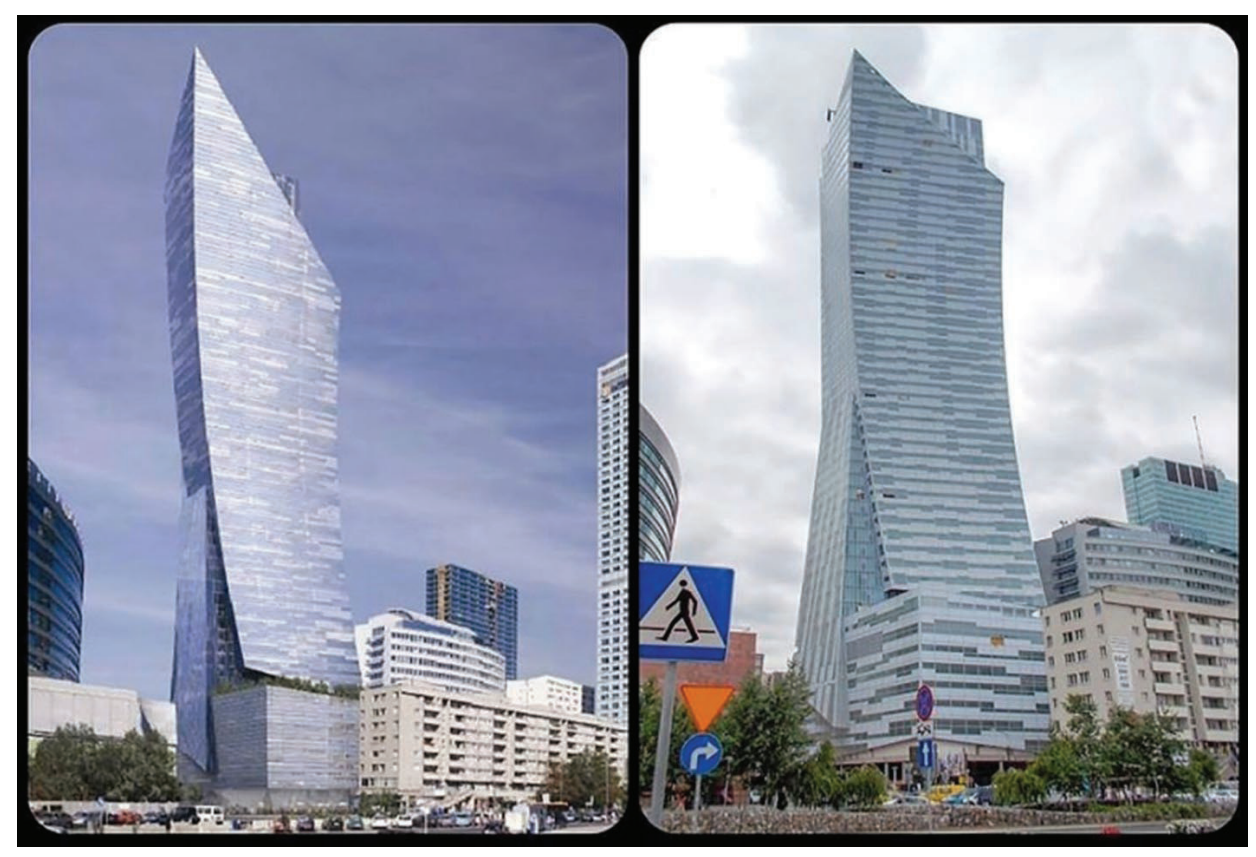

Il. 3. Zestawienie wizualizacji (po lewej) i zdjęcia (po prawej) budynku przy ul. Złotej 44 w Warszawie (proj. D. Liebeskind) (źródło: [12];

autor zestawienia o charakterze internetowego mema i zdjęcia po prawej nieznany)

Fig. 3. Juxtaposition of a visualisation (left) and a photograph (right) of the building at 44 Zlota Street in Warsaw (by D. Liebeskind) (source: [12], the author of the comparison functioning as the internet meme and the right photograph are unknown)
Wizualizacja została wykonana na potrzeby projektu wieżowca przy użyciu zdjęcia lokalizacji jako tła (dokonano tu edycji polegającej m.in. na likwidacji trzeciego zbiegu i wyrównaniu wartości tonalnych ciemniejszych partii), w które wstawiono syntetyczny obraz budynku powstały na bazie wirtualnego trójwymiarowego modelu. Z kolei zdjęcie użyte w zestawieniu sprawia wrażenie wykonanego za pomocą aparatu w telefonie komórkowym, bez żadnej ingerencji.

Przytoczone zestawienie nasuwa pytanie, na ile odmienna proweniencja obrazów determinuje ich odbiór i w jakim stopniu syntetyczny charakter pierwszego z nich decyduje o tym, że może on być komentowany jako nieodpowiadający rzeczywistości. Fotorealistyczny ${ }^{11}$ charakter wizualizacji skłania do postawienia pytania, czy przy użyciu dostępnych narzędzi edycji obrazu oraz przy zachowaniu konwencji fotografii architektury (w szczególności usunięcia trzeciego zbiegu ${ }^{12}$ ) możliwe jest wykonanie zdjęcia przedstawiającego omawiany budynek w sposób zbliżony do wspomnianego obrazu stworzonego

11 Określenie,,fotorealistyczny”, jakkolwiek powszechnie przyjęte, należałoby dla rzetelności dyskursu zastąpić przez „fotomimetyczny” na zasadzie analogii pomiędzy realizmem i mimetyzmem w sztuce.

${ }^{12}$ Kwestia korekcji zbiegających się linii pionowych, w przypadku fotografii powstałych $\mathrm{w}$ wyniku odchylenia obszaru projekcji w aparacie fotograficznym (kliszy lub matrycy) od pionu, jest zagadnieniem wielowątkowym i wykracza poza ramy niniejszego artykułu. Wiąże się to ze skomplikowanymi procesami percepcji rzeczywistości trójwymiarowej zapośredniczonej przez jej płaską reprezentację, co jest polem zainteresowań kognitywistów; por. [13, s. 192, 193]. Zasygnalizować tu można kwestię całkowicie różnych mechanizmów tworzenia obrazu fotograficznego i obrazu percepcyjnego, gdzie ten ostatni jest bardziej konceptem mentalnym niż konkretną projekcją podlegającą prawom geometrii. Każde odchylenie osi optycznej aparatu fotograficznego powoduje nierównoległość odwzorowywanych linii pionowych, podczas gdy spojrzenie nieco ku górze nie powoduje takiego wrażenia - bodźce wizualne są bowiem integrowane przez mózg, czego wynikiem jest „skorygowana" percepcja. tools of image editing and by preserving the conventions of architectural photography (particularly by removing the third vanishing point ${ }^{13}$ ), it is possible to take a photograph of this building in a similar way to the computer-generated image mentioned. This attempt resulted in a photograph presented in the comparison with the aforementioned visualisation (Fig. 4).

The operations mentioned above allowed us to prepare the final comparison of images of the same provenance (Fig. 5): each of them is a photograph. The first of them was edited in a mode characteristic for architectural convention, which is being popularly reused in the case of visualisation. The second one creates an impression of a random frame, as if in motion. This pair of images was presented to the respondents of the survey with a request to answer the following question: "Which of the presented photographs conveys the reality in a more faithful way? Briefly justify your answer".

214 anonymous responses were collected. The number of responses indicating photograph 1 as corresponding more closely to reality amounted to 64 , while the latter photograph was chosen by 150 respondents. Thus, the vast majority of respondents $(70 \%)$ indicated the unedited photograph

13 The question of "correction" of converging vertical lines in the case of photographs produced as a result of inclining the projection area in a camera (photographic film or image sensor) from the vertical, is a multifaceted issue beyond the scope of this article. It is related to complicated processes of perception of three-dimensional reality rendered by means of its plane representation, which falls within the scope of interest of cognitivists [13, pp. 192, 193]. It should be noticed here that there exist totally different mechanisms for creating a photographic and perceptive image, where the latter is more of a mental concept than a concrete projection, subject to laws of geometry. Every inclining of an optical axis in a photographic camera causes a disparallelism of represented vertical lines, whereas a slightly upward look does not create such an impression - for visual stimuli are integrated by the brain, which results in a "corrected" perception. 
I1. 4. Zestawienie zdjęcia (po lewej, fot. K. Koszewski)

z wizualizacją (po prawej, źródło: [12]) budynku

przy ul. Złotej $44 \mathrm{w}$ Warszawie

Fig. 4. Juxtaposition of a photograph

(left photo by K. Koszewski) and a visualisation (right, source: [12]) of the building

at 44 Zlota Street in Warsaw

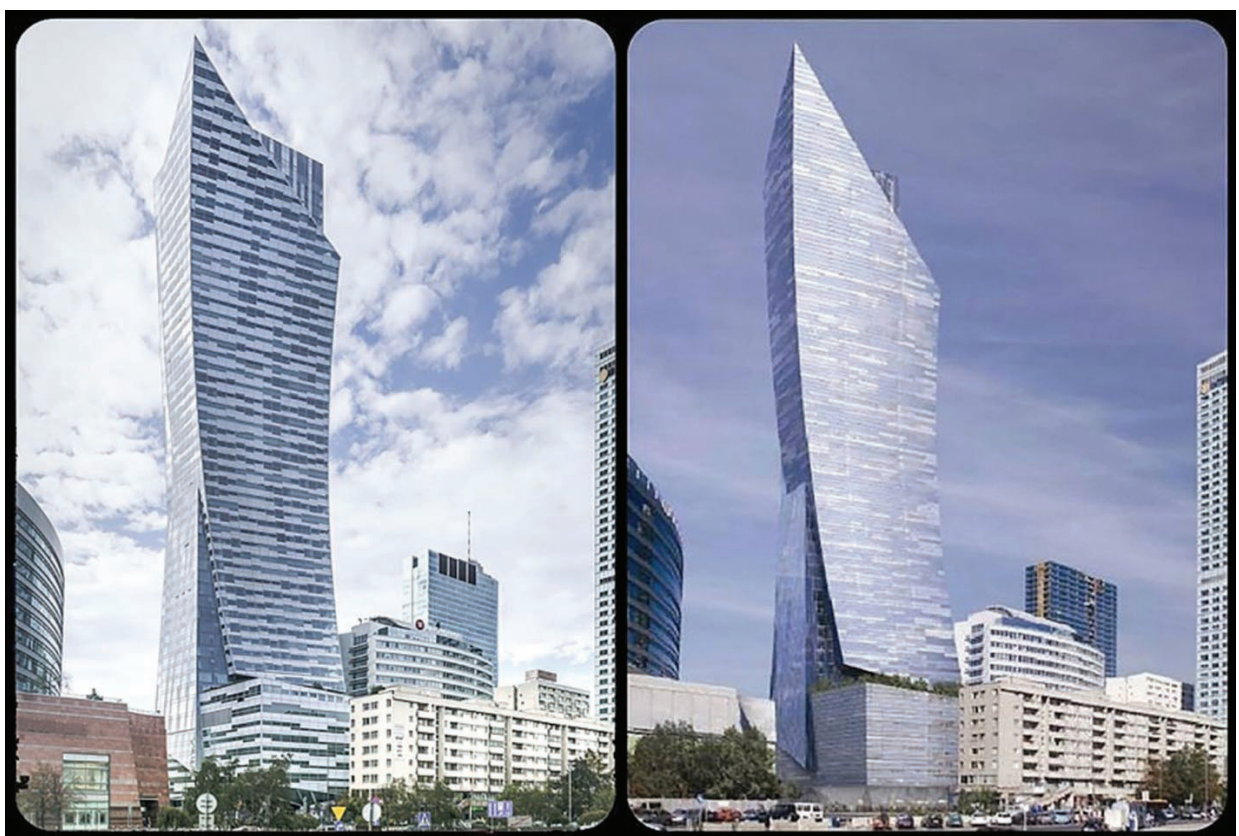

komputerowo. Podjęta próba zaowocowała zdjęciem ukazanym w zestawieniu ze wspomnianą wizualizacją (il. 4).

Powyższe operacje pozwoliły ostatecznie przygotować zestawienie obrazów o jednakowej proweniencji (il. 5): każdy z nich jest zdjęciem. Jedno z nich zostało poddane obróbce charakterystycznej dla konwencji fotografii architektury, która chętnie jest powielana w przypadku wizualizacji. Drugie sprawia wrażenie przypadkowego kadru, wykonanego jakby w biegu. Tę parę obrazów przedstawiono respondentom ankiety, prosząc o odpowiedź na pytanie: „Które z przedstawionych zdjęć wierniej oddaje rzeczywistość? Odpowiedź krótko uzasadnij”.

Zebrano 214 anonimowych odpowiedzi. Liczba odpowiedzi wskazujących na zdjęcie numer 1 jako bardziej odpowiadające rzeczywistości wyniosła 64 , podczas gdy as more faithful in relation to their direct experience. Among 214 responses, 16 people named the third vanishing point as a factor causing the lack of faithful representation of reality. In contrast, 48 people pointed to the act of eliminating the third vanishing point (making the vertical lines parallel) as such factor. Over half of the respondents (109 people) claimed that the cause of unfaithfulness of the representation lies in the disturbed proportions (of which 36 people ranked this factor as disqualifying for photograph 2 , whereas 73 saw disturbed proportions in photograph 1).

This outcome is interesting since the convention employed with the first photograph is predominant in the case of visualisations of students projects (as well as commercial projects at later stages) which operate the language of photomimetism.

Il. 5. Zestawienie zdjęć zaprezentowane respondentom: zdjeccie numer 1 - wykonane podobnie jak zdjęcie będące tłem wizualizacji z ilustracji 1 oraz zdjęcie numer 2

(autor nieznany; źródło: [12]) - wykonane bez żadnych korekcji

Fig. 5. Comparison of photographs presented to the respondents:

photograph 1 - performed in a similar way to the photo which

is a visualisation background from illustration 1 and photograph 2

(author unknown, source: [12]) - in unedited version

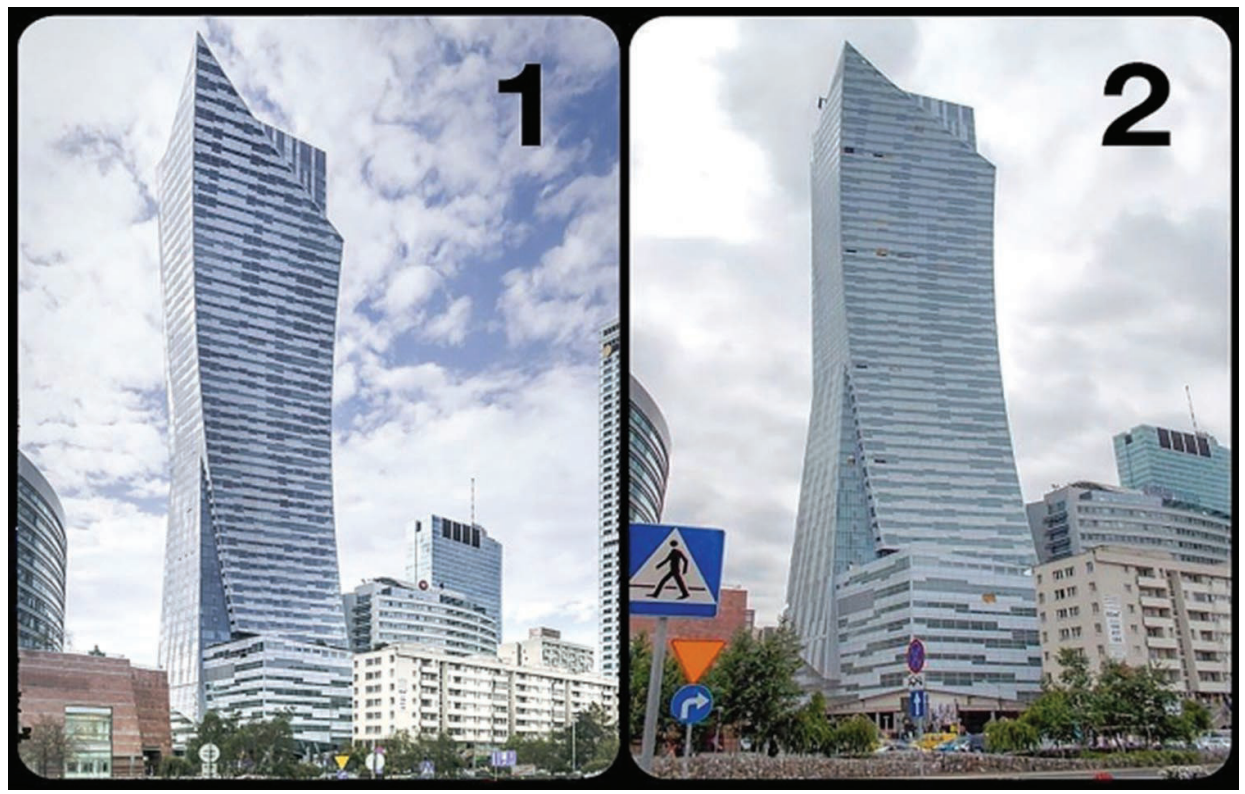


drugie zdjęcie wybrało 150 respondentów. Tym samym znaczna większość badanych $(70 \%)$ wskazała zdjęcie bez korekcji jako wierniejsze w stosunku do ich bezpośredniego doświadczenia. Spośród 214 udzielonych odpowiedzi 16 osób wskazało trzeci zbieg jako czynnik powodujący brak wiernego odwzorowania rzeczywistości. Z kolei 48 osób wymieniło jako taki czynnik zabieg likwidacji trzeciego zbiegu (doprowadzenie do równoległości linii pionowych). Ponad połowa (109 osób) stwierdziła natomiast, że powodem braku wierności odwzorowania są zaburzone proporcje (w tym 36 osób oceniło ten powód jako dyskwalifikujący dla zdjęcia 2, zaś 73 widziało zaburzone proporcje na fotografii 1 ).

Wynik ten jest dlatego ciekawy, że konwencja zastosowana $\mathrm{w}$ zdjęciu pierwszym jest dominująca w przypadku wizualizacji projektów studenckich (jak i później komercyjnych) operujących językiem fotomimetyzmu. Wspomniany już brak trzeciego zbiegu jest tu regułą, od której wyjątki stanowią kadry celowo przesadnie dynamiczne. Jeśli zatem przyjąć takie założenie, to należy stwierdzić, że konwencja prezentacji idei architektonicznych (w przypadku tych przedstawień, które preferują ukazywanie koncepcji w sposób zbliżony do fotografii, zatem wspomnianych wcześniej „odwróconych retrospekcji”) wybierana jest ze świadomością, że nie stanowi ona odzwierciedlenia przyszłej, kreowanej rzeczywistości. Są to konstatacje, które wymagają dalszych badań w zakresie praktyk wizualnych w architekturze, albowiem proste wyjaśnienie wskazujące na marketingowe funkcje wizualizacji (powodujące idealizację obrazu) wydaje się tu niewystarczające.

Warto, w ramach analiz jakościowych, przytoczyć charakterystyczne odpowiedzi na pytanie dotyczące przesłanek wyboru obrazu. Podzielone one zostały na dwie grupy: te, które uzasadniały wybór zdjęcia 1 , oraz te, które wskazywały na zdjęcie 2 jako wierniejsze.

Osoby, które wybrały zdjęcie 1 jako bardziej odpowiadające rzeczywistości, uzasadniały to w następujący sposób (cytaty z ankiet):

- „Ponieważ budynek wydaje się smuklejszy, większy i lepiej oddaje wyobrażenie o jego wielkości i kształtach oraz jego relacjach z innymi budynkami”.

- „Trzeci zbieg na 2 zdjęciu przeszkadza w odbiorze miejsca. Przez to, że znaki drogowe na pierwszym planie kończą się gdzieś poza kadrem, nie czyta się kompletnie przestrzeni na zdjęciu. Brak takich „błędów” na pierwszym zdjęciu daje więcej informacji o miejscu i przestrzeni”.

- „Na pierwszym budynek jest bardziej strzelisty, i tak go właśnie kojarzę. Pewnie głównie dlatego, że najczęściej widuję go na zdjęciach, które robione są z lotu ptaka i tam właśnie jest strzelisty".

- „Nawet jeśli nie wygląda dokładnie tak z tamtego miejsca, to takim się go zapamiętuje. Czyli pewnie w rzeczywistości taki właśnie jest!’”

- „Drugie zdjęcie lepiej odzwierciedla odczucia przechodniów do tego budynku (rozczarowanie względem pokazywanych wizualizacji, toporność brył), jednak zdjęcie numer 1 pokazuje obraz bliższy prawdy".

$\mathrm{Z}$ kolei osoby wskazujące na zdjęcie 2 tak to krótko uzasadniały:
The lack of the third vanishing point mentioned above is the rule here, the exceptions being intentionally over dynamic frames. Therefore, if such an assumption is to be made, it should be claimed that the convention of presenting architectural ideas (in the case of those presentations, which prefer to show conceptions in a similar mode to photography, thus the "reverse retrospections" mentioned before) is selected bearing in mind that it does not constitute a reflection of the future created reality. These are constatations which require further research in the area of visual practices in architecture since a simple explanation pointing to the marketing functions of visualisation (causing image idealisation) seems to be insufficient.

As part of qualitative analyses, it is worth quoting characteristic answers to the question about the premises for choosing the image. They were divided into two groups, i.e. the first justified the choice of photograph 1 , and the other opted for photograph 2 as more faithful.

The respondents who chose photograph 1 as corresponding closer to reality justified their choice in the following way (quotes from the survey):

- "Because the building seems more slender, larger and better projects the image of its size and shapes as well as its relations to other buildings".

- "The third vanishing point in photograph 2 disturbs the reception of the site. Since the road signs in the foreground reach somewhere outside of the frame, the space in the photograph is completely impossible to read. Lack of such 'mistakes' in the first photograph gives more information about the place and space".

- "In the first photograph the building is more towering, and this is how I see it. Probably mainly because I see it most often in the photographs which are taken from the bird's view and in those photographs it is towering".

- "Even if it does not look exactly this way from that place, that's how you remember it. So this is probably what it looks like in reality".

- "The second photograph reflects better the feelings of passers-by towards this building (disappointment with the presented visualisations, bulkiness of structures), but the first photograph shows the picture which is closer to the truth".

In contrast, the people opting for the second photograph justified their choices as follows:

- "The first photograph is of course more visually attractive (but this is a visualisation, isn't it?) and shows better the idea, but it is in the second photograph that the real shape of the building is shown".

- "Photograph 2 renders the reality better because elements of everyday life are more noticeable here, inherent elements of urban tissues such as road signs".

- "Photograph 2 looks as if it was taken with a smartphone by an accidental passer-by - he took the photograph the way he saw it and went on, not even trying to take the photo which would show the building from its best side. Photograph 1 seems to be a visualisation, idealised reality".

- "Number 1 is idealised, this photograph looks as if it was produced by a professional photographer, which could be found e.g. in a magazine. Number 2 presents the 
- „Zdjęcie nr 1 jest oczywiście bardziej atrakcyjne wizualnie (ale to chyba wizualizacja?) i lepiej pokazuje ideę, natomiast to właśnie na zdjęciu 2 jest pokazana rzeczywista bryła tego budynku".

- „Zdjęcie 2 lepiej oddaje rzeczywistość, ponieważ bardziej zauważalne są na nim elementy codzienności, nieodłączne elementy tkanki miasta takie jak znaki drogowe".

- „Zdjęcie nr 2 wygląda, jakby zostało zrobione aparatem $\mathrm{z}$ telefonu przez przypadkowego przechodnia - tak jak zobaczył, tak zrobił zdjęcie i poszedł dalej, nawet nie starając się wykonać zdjęcia ukazującego budynek z jak najlepszej strony. Zdjęcie nr 1 wydaje się być wizualizacją, wyidealizowaną rzeczywistością".

- „1 jest wyidealizowana, to zdjęcie wygląda na zrobione przez profesjonalnego fotografa, mogące znaleźć się w np. magazynie. 2. przedstawia brutalną rzeczywistość, nie zawsze patrzymy pod odpowiednim kątem, przy ładnej pogodzie i dobrym świetle".

- „Wygląda brzydziej, więc to prawdziwe zdjęcie. Rzeczywistość nie jest kolorowa".

Z przytoczonych powyżej opinii, które można streścić w stwierdzeniu, że wizualizacja nie odpowiada (projektowanej) rzeczywistości, (po zrealizowaniu) nieatrakcyjnej i odbiegającej od wizji architekta, można wyciągnąć następujące wnioski:

1. Respondenci mają świadomość ułomności konwencji, która jest odczytywana w duchu fotomimetyzmu i odwróconej retrospekcji (rozczarowanie wizualizacją jako niespełnioną obietnicą). Praktyka wskazuje jednak, że mimo to często posługują się nią w trakcie tworzenia komunikatu wizualnego prezentującego ideę własnego projektu.

2. Akceptacja konwencji przedstawiania architektury na zdjęciach (,zdjęcie wygląda na zrobione przez profesjonalnego fotografa, mogące znaleźć się w np. magazynie") nie idzie w parze $\mathrm{z}$ krytyczną jej ewaluacją i odbiorem.

3. Język obrazów architektury staje się samoreferencyjny (widziałem budynek na zdjęciach, więc zapewne tak wygląda), a przez to hermetyczny i o ograniczonej skuteczności.

4. Praktyki stosowane w tworzeniu komunikatu wizualnego w obszarze architektury stoją w sprzeczności z wyrażaną opinią na temat ich istoty.

\section{Wnioski - postulaty dotyczace dydaktyki architektonicznej}

Zarówno ilościowe, jak i jakościowe interpretacje przeprowadzonej ankiety skłaniają do sformułowania postulatów dotyczących samego procesu dydaktycznego. Uzupełniając i reinterpretując dziedzictwo Bauhausu w zakresie nauczania architektury, należy zadbać nie tylko o wrażliwość i kreatywność, nie tylko o warsztatowe umiejętności stworzenia adekwatnego i czytelnego komunikatu wizualnego, ale także o zdolność krytycznej ewaluacji języka obrazów - także w zakresie ich tworzenia - oraz o świadomość możliwych scenariuszy i schematów ich funkcjonowania. Tworzony przekaz staje się, niezależnie od intencji projektantów, elementem obrazowego uniwersum harsh reality, we do not always look from the right angle, in nice weather and in good light".

- "It looks uglier, so it is the real photograph. Reality is not colourful".

From the opinions quoted above, which might be summarised in a statement that visualisation does not correspond to (designed) reality, (after completion) unattractive and deviating from architect's vision, the following conclusions may be drawn:

1. The respondents are aware of the defectiveness of convention, which is interpreted in the spirit of photomimetism and reverse retrospection (disappointment with visualisation as an unfulfilled promise). Practice shows, however, that in spite of this, they frequently make use of the convention, while creating a visual message presenting the idea of their own project.

2. Accepting the convention of presenting architecture in photographs ("the photo looks as if it was taken by a professional photographer which could be found e.g., in a magazine") does not go hand in hand with its critical evaluation and reception.

3. The language of architectural images is becoming self-referential ("I saw the building in photographs so it probably looks like that"), and hence hermetic and of limited effectiveness.

4. Practices employed in creating a visual message in the realm of architecture contradict the opinion expressed on their essence.

\section{Conclusions - postulates of architectural didactics}

Both quantitative and qualitative interpretations of the conducted survey provoke to lay down requirements for the teaching process itself. When complementing and reinterpreting the Bauhaus heritage in teaching architecture, one should not only care for the sensitivity and creativity or the methods and ability to create an adequate and clear visual message, but also for the ability to critically evaluate the language of images, in terms of their creation as well, and being aware of possible scenarios and schemas of their functioning. Independently of the designers' intentions, the created message becomes an element of a pictorial ensemble of modern culture, which, acting as a feedback loop, has an impact on both architecture itself and, in particular, on the possibilities of realising a particular concept. The reception of already constructed architectural pieces occurs mostly through images constituting modern visual culture, independently of imperfections in this kind of message as compared to hands-on experience. It is necessary to indicate and understand the main characteristics of this kind of message, which is useful both at the stage of formulating the message and its reception. The importance of critical analysis of architectural images should be emphasised as a cultural fact. It is crucial in the process of architectural learning. Visual practices in which architects participate go beyond the designing methods and skills understood as a restrictive interpretation of Bauhaus ideas, which is rarely reflected in teaching. Not increasing the scope of didactic interests 
współczesnej kultury, wpływając na zasadzie sprzężenia zwrotnego zarówno na samą architekturę, jak i - w szczególności - na możliwości urzeczywistnienia konkretnej koncepcji. Odbiór dzieł architektury już wzniesionych jest zapośredniczony w dużej mierze przez obrazy, będące przy tym elementem współczesnej kultury wizualnej, niezależnie od ułomności tego typu przekazu w porównaniu $\mathrm{z}$ bezpośrednim doświadczeniem. Konieczne jest wskazanie i zrozumienie głównych cech charakterystycznych dla tego typu przekazu, przydatne zarówno na etapie formułowania komunikatu, jak i jego odbioru. Należy podkreślić wagę krytycznej analizy obrazów architektury jako faktu kulturowego. Ma ona kluczowe znaczenie w procesie kształcenia architektonicznego. Praktyki wizualne, będące udziałem architektów, wykraczają poza ramy warsztatu projektowego rozumianego jako wąska interpretacja idei Bauhausu, co rzadko znajduje odzwierciedlenie w nauczaniu. Brak poszerzenia pola zainteresowań dydaktycznych o ten właśnie obszar pozbawia dydaktykę - i późniejszą praktykę - bardzo istotnego, szerszego kontekstu, mającego decydujący charakter $\mathrm{w}$ procesie powstawania dzieła architektury. Słowa Gropiusa odnoszące się do „wrodzonej predylekcji człowieka do postrzegania życia jako całości” [3, s. 30] można - i należy - interpretować także w ten sposób.

Przedstawiając w podsumowaniu konkretne wnioski w odniesieniu do dydaktyki architektonicznej, należałoby zatem wymienić odpowiednie kompetencje i umiejętności, które powinny być wynikiem kształcenia. Są to:

- kompetencje w zakresie interpretowania i tworzenia architektonicznego przekazu wizualnego w szerokim kontekście współczesnej ikonosfery,

- umiejętność dostrzeżenia, zrozumienia i krytycznej interpretacji komunikatu wizualnego,

- skuteczne tworzenie komunikatu wizualnego w określonym obszarze rzeczywistości - projektowaniu architektonicznym,

- umiejętność wartościowania komunikatów wizualnych i przywoływanie ich w przestrzeni umysłu. by this area deprives didactics - and further practice - of an extremely important and wider context, which plays a decisive role in the process of creating an architectural piece. Gropius' words referring to "inborn human predilection to perceive life as a whole" [3, p. 30] may - and should - be interpreted in this way, too.

When presenting specific conclusions on architectural didactics, it would be necessary to list the following appropriate competences and skills which should result from the process of learning:

- competence in interpreting and creating an architectural visual message in a wide context of contemporary iconosphere,

- the ability to notice, understand, and critically interpret a visual image,

- effective creation of a visual message in a specific area of reality - architectural design,

- the ability to evaluate visual messages and evoke them in our minds.

Translated by Ewa Furyk, Agnieszka Tomaszkiewicz

\section{Bibliografia/References}

[1] Gropius W., Programm des Staatlichen Bauhauses in Weimar, Staatliches Bauhaus, Weimar 1919.

[2] Naylor G., Bauhaus, Wydawnictwa Artystyczne i Filmowe, Warszawa 1977

[3] Preisich G., Walter Gropius, Arkady, Warszawa 1981.

[4] Kandinsky W., Punkt i linia a plaszczyzna. Przyczynek do analizy elementów malarskich, PIW, Warszawa 1986.

[5] Gropius W., Petnia architektury, Karakter, Kraków 2014.

[6] Mitchell W.J.T., The pictorial turn, „Artforum International” 1992, Vol. 30, No. 7, 89-94.

[7] Jencks Ch., Architektura postmodernistyczna, Arkady, Warszawa 1987.

[8] Barthes R., Retoryka obrazu, [w:] M. Skwara, S. Wysłouch (red.), Ut pictura poesis, Słowo/obraz terytoria, Gdańsk 2006, 139-158.
[9] Plac Defilad z zielenia $i$ woda. Ale co tam robi ta świnia?, TVN Warszawa, 2018, https://tvn24.pl/tvnwarszawa/najnowsze/plac-defilad-z-zielenia-i-woda-brale-co-tam-robi-ta-swinia-280120 [accessed: 20.03.2020].

[10] Koszewski K., Obrazy architektury: reprezentacje idei architektonicznej w kontekście współczesnej kultury wizualnej, Oficyna Wydawnicza PW, Warszawa 2019.

[11] Porębski M., Ikonosfera, PIW, Warszawa 1972.

[12] van Vallendael K., Żagiel Libeskinda Złota 44. Projekt a rzeczywistość w żartach internautów, Warszawa-naszemiasto.pl, 2013. http:// warszawa.naszemiasto.pl/artykul/zagiel-libeskinda-zlota-44-projekt-a -rzeczywistosc-w,1957574,artgal,t,id,tm.html [accessed: 30.11.2019].

[13] Pick H., Walk R.D., Perception and Experience, Springer, New York 2013. 


\section{Streszczenie}

Artykuł zawiera rozważania odnoszące się do miejsca obrazów architektury we współczesnej kulturze wizualnej. Analiza ta jest prowadzona na tle założeń programowych Bauhausu, wskazując potrzebę ich reinterpretacji z uwzględnieniem roli współczesnej kultury wizualnej jako istotnego elementu warunkującego przekaz idei architektonicznej. Odnosi się do zjawiska odwróconej retrospekcji - mechanizmu przeniesienia konotacji znaczeniowych właściwych dla fotografii na sferę komunikatu architektonicznego. Celem pracy jest wskazanie wynikających z powyższych analiz wniosków, które można zastosować we współczesnej dydaktyce architektonicznej.

Rozważania wsparto badaniami ankietowymi dotyczącymi świadomości wizualnej studentów pierwszych lat kierunku architektura. Prezentowane wyniki poddano analizie w zakresie zarówno jakościowym, jak i ilościowym, przedstawiając także ich interpretację.

Na zakończenie sformułowano wnioski dotyczące nauczania architektury: uzupełniając i reinterpretując dziedzictwo Bauhausu konieczne jest zwrócenie uwagi nie tylko na umiejętności tworzenia adekwatnego i czytelnego komunikatu wizualnego, ale także na zdolność krytycznej ewaluacji języka obrazów oraz świadomość możliwych scenariuszy i schematów ich funkcjonowania. Tworzony przekaz staje się, niezależnie od intencji projektantów, elementem obrazowego uniwersum współczesnej kultury, wpływając na zasadzie sprzężenia zwrotnego zarówno na samą architekturę, jak i - w szczególności - na możliwości urzeczywistnienia konkretnej koncepcji. W tym kontekście autor uważa omawiane zagadnienia za niezwykle istotne i godne dalszych badań zarówno z punktu widzenia dydaktyki architektonicznej, jak i uprawiania zawodu.

Slowa kluczowe: dydaktyka architektoniczna, obrazy architektury, przekaz wizualny w architekturze, Bauhaus

\section{Abstract}

The paper contains reflections on the place of architectural images in modern visual culture. This analysis is conducted in the context of Bauhaus postulates, indicating the need to reinterpret them and include the role of modern visual culture as a crucial element determining the message of architectural ideas. The analysis makes a reference to the phenomenon of reverse retrospection - a mechanism of transferring semantic associations typical for photographs to the sphere of architectural message. The purpose of this paper is to indicate conclusions resulting from the aforementioned analyses, which can be applied in modern architectural didactics.

The reflections were supported by survey research on the visual awareness of first-years' students of architecture. The presented findings were analysed both qualitatively and quantitatively, and their interpretation was included as well.

Finally, conclusions on teaching architecture were drawn, i.e. when complementing and reinterpreting the Bauhaus heritage, it is necessary to pay attention not only to the ability to create an adequate and clear visual message, but also to the ability to critically evaluate the language of images and being aware of possible scenarios and schemas of their functioning. Independently of the designers' intentions, the created message becomes an element of a pictorial ensemble of modern culture, which, acting as a feedback loop, has an impact on both architecture itself and, in particular, on the possibilities of realising a particular concept. In this context the author considers the discussed issues to be extremely important and worth further research, both from the point of view of the architectural didactics and the profession of architect.

Key words: architectural didactics, architectural images, visual message in architecture, Bauhaus 


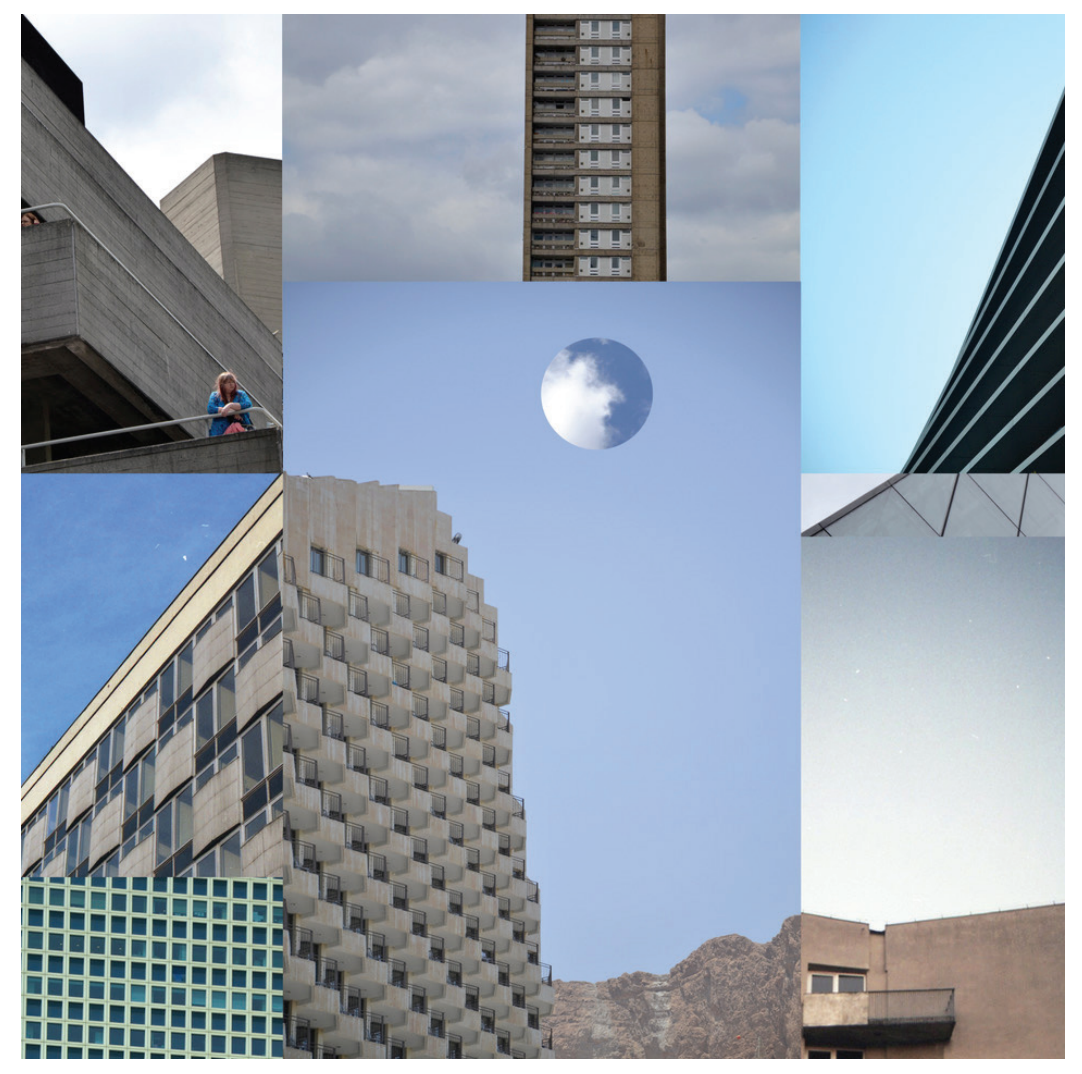

Fotografia cyfrowa, kolaż

(W. Kozak)

Digital photography, collage (W. Kozak) 